\title{
UJI USABILITY DENGAN METODE COGNITIVE WALKTHROUGH DAN SYSTEM USABILITY SCALE (SUS) PADA SITUS WEB STT WASTUKANCANA
}

\author{
USABILITY TEST USING COGNITIVE WALKTHROUGH AND SYSTEM \\ USABILITY SCALE (SUS) METHODS ON STT WASTUKANCANA WEBSITE
}

\author{
Meriska Defriani ${ }^{1}$, Mochzen Gito Resmi ${ }^{2}$, Irsan Jaelani ${ }^{3}$ \\ Teknik Informatika, STT Wastukancana \\ meriska@stt-wastukancana.ac.id
}

\begin{abstract}
STT Wastukancana website is one of the information media regarding institutional activities, both for students, lecturers, educational staff, and the wider community. Apart from being a medium of information, STT Wastukancana website is also connected to various information systems in institutions such as academic information systems. Ease of information retrieval and a good experience when using the website are very important. Therefore, in this study, an interface evaluation was carried out by conducting usability testing. Usability aspects that are evaluated are learnability, effectiveness, efficiency, and satisfaction. The test was conducted using the cognitive walkthrough method on 10 respondents, either those who have not or have used the STT Wastukancana website and the system usability scale (SUS) on 20 respondents who have used the STT Wastukancana website. The results of this study show that the learnability aspect is $96 \%$, the effectiveness is 96\%, the efficiency is 0.07 seconds, and the satisfaction aspect is SUS 86.25 and acceptability ranges are in the acceptable category. Recommendations for improving the usability of the STT Wastukancana website consist of two types of recommendations, namely interface improvements and system improvements.
\end{abstract}

Keywords: Usability Testing, Cognitive Walkthrough, System Usability Scale.

\begin{abstract}
ABSTRAK
Situs web STT Wastukancana merupakan salah satu media informasi mengenai kegiatan institusi, baik untuk mahasiswa, dosen, tenaga kependidikan, maupun masyarakat luas. Selain sebagai media informasi, situs web STT Wastukancana juga terhubung dengan berbagai sistem informasi yang ada di institusi seperti sistem informasi akademik. Kemudahan pencarian informasi dan pengalaman yang baik saat menggunakan situs web tersebut sangatlah penting. Oleh karena itu, pada penelitian ini dilakukan evaluasi antarmuka dengan melakukan pengujian usability. Aspek usability yang dievaluasi adalah learnability, effectiveness, efficiency, dan satisfaction. Pengujian dilakukan dengan menggunakan metode cognitive walkthrough pada 10 orang responden, baik yang belum atau sudah pernah menggunakan situs web STT Wastukancana dan system usability scale (SUS) pada 20 responden yang sudah pernah menggunakan situs web STT Wastukancana. Hasil dari penelitian ini diperoleh nilai aspek learnability sebesar 96\%, effectiveness sebesar 96\%, efficiency sebesar 0,07 detik, dan aspek satisfaction dengan nilai SUS 86,25 dan acceptability ranges berada di kategori acceptable. Rekomendasi perbaikan usability situs web STT Wastukancana terdiri dari dua jenis rekomendasi, yaitu perbaikan antarmuka dan perbaikan sistem.
\end{abstract}

Kata Kunci: Pengujian Usability, Cognitive Walkthrough, System Usability Scale.

\section{PENDAHULUAN}

STT Wastukancana merupakan salah satu sekolah tinggi yang berada di Kabupaten Purwakarta. Terdapat dua jenjang program studi yang diselenggarakan, yaitu D3 dan S1. Program studi yang termasuk dalam jenjang D3 adalah Manajemen Industri dan Teknik Tekstil. Program studi yang termasuk dalam jenjang S1 adalah Teknik Informatika, Teknik Industri, dan Teknik Mesin. Untuk penyebaran informasi mengenai kegiatan institusi, STT Wastukancana memiliki media informasi berupa situs web. Media tersebut juga digunakan sebagai media 
untuk promosi sehingga tidak hanya dapat diakses oleh sivitas akademika tapi juga dapat diakses oleh masyarakat luas. Selain itu, media tersebut juga terhubung dengan berbagai sistem informasi yang ada di institusi seperti Sistem Informasi Akademik (SIMAK). Kemudahan pencarian informasi dan pengalaman yang baik saat menggunakan situs web tersebut merupakan hal yang penting. Oleh karena itu, perlu dilakukan evaluasi antarmuka pada situs web STT Wastukancana.

Pada penelitian ini dilakukan pengujian usability pada situs web STT Wastukancana. Usability merupakan aspek penting untuk menilai kualitas antarmuka pengguna dan mengurangi kerugian pengguna dalam menggunakan sistem(Arijaya et al., 2019). Aspek usability yang dievaluasi adalah learnability, effectiveness, efficiency, dan satisfaction. Pengujian dilakukan dengan menggunakan metode cognitive walkthrough pada 10 orang responden. Metode cognitive walkthrough digunakan untuk mengetahui permasalahan pada aspek learnability, effectiveness, dan efficiency. Metode Cognitive Walkthrough merupakan metode evaluasi usability dimana satu atau lebih evaluator bekerja melalui serangkaian skenario tugas dan meminta sejumlah pertanyaan dari perspektif pengguna(Bligard \& Osvalder, 2013). Pengujian juga dilakukan dengan menggunakan System Usability Scale (SUS) pada 20 responden yang sudah pernah menggunakan situs web STT Wastukancana. SUS digunakan untuk mengetahui aspek satisfaction. SUS adalah salah satu metode uji pengguna yang menyediakan alat ukur yang cepat dan andal. SUS dapat digunakan untuk menilai kelayakan berbagai produk dan layanan. Dengan menggunakan metode SUS, responden dapat dengan cepat dan mudah menyelesaikan pertanyaan
kuesioner(Pradini et al., 2019). Pengujian usability ini akan dilakukan pada sejumlah total 35 orang responden responden yang terdiri dari mahasiswa, dosen, tenaga kependidikan, dan masyarakat.

Hasil pengujian usability ini dapat menjelaskan permasalahan apa saja yang dihadapi pengguna dan menggambarkan sejauh mana ketercapaian aspek-aspek usability pada situs web STT Wastukancana. Berdasarkan penjelasan dan gambaran tersebut kemudian dapat diusulkan perbaikan apa saja yang harus dilakukan pada tampilan situs web STT Wastukancana sehingga nantinya dapat memberikan pengalaman yang baik kepada pengguna. Pengguna dapat merasa nyaman untuk mengakses situs web tersebut di waktu yang akan datang.

Pada tahun 2016, metode cognitive walkthrough pernah digunakan untuk menguji usability situs web perpustakaan di Universitas Mercu Buana Jakarta dan menghasilkan nilai penyelesaian skenario sebesar 90\%(Raharjo et al., 2016). Pada tahun 2017, metode ini juga digunakan untuk menguji usability antarmuka aplikasi braile smart dan menghasilkan nilai ratarata usability sebesar $68,3 \%$ (Kurnia et al., 2017). Pada tahun 2019, metode cognitive walkthrough dan system usability scale digunakan untuk menguji usability website e-commerce dan menghasilkan nilai aspek learnability sebesar $86 \%$, effectiveness sebesar $24 \%$, efficiency sebesar 0,02 detik, dan satisfaction diperoleh nilai 57,625(Kusumah et al., 2019).

\section{METODE}

Metode penelitian yang digunakan adalah literatur review serta pengujian usabilitry dengan metode Cognitive Walkthrough dan System Usability Scale (SUS). Berikut ini adalah penjelasan terkait metode yang digunakan: 


\section{Usability}

Usability dapat diartikan sebagai suatu alat yang digunakan untuk mengukur kualitas suatu perangkat lunak, sistem informasi, atau juga website. Hal ini berkaitan dengan kemudahan dalam mempelajari dan menggunakan suatu sistem sehingga mendorong pengguna untuk menggunakan sistem tersebut sebagai pembantu dalam menyelesaikan tugas(Setiawati et al., 2018). Usability menjelaskan tentang sejauh mana suatu produk atau layanan yang telah ada dapat dimanfaatkan oleh pengguna untuk mencapai tujuan dan kebutuhan pengguna(Audi et al., 2018). Berdasarkan penjelasan tersebut dapat diartikan bahwa usability merupakan ukuran efektifitas, efisiensi, dan kepuasan pengguna dalam menggunakan sebuah produk untuk mencapai tujuan(Aprilia et al., 2015). Usability sebuah sistem memiliki lima komponen yaitu learnability, efficiency, memorability, errors, dan satisfaction(Nielsen, 2012).

\section{Uji Usability}

Proses uji usability menjelaskan informasi secara langsung dari pengguna mengenai bagaimana pengguna menggunakan sistem serta masalah yang dihadapi. Hasil pengamatan terhadap bagaimana pengguna berinteraksi dengan fitur-fitur yang ada pada situs web menggambarkan bagaimana pembelajaran dan keberhasilan pengguna dalam mengakses situs web. Pada uji usability akan diperoleh sejumlah permasalahan usability yang belum diketahui solusinya. Dalam beberapa waktu, uji usability akan mempelajari bagian-bagian pada situs web yang sulit digunakan atau dimengerti oleh pengguna. Pada uji usability tidak berfokus pada kelayakan tetapi juga praktik berkelanjutan, memiliki potensi yang mengakibatkan perubahan atau perbaikan yang besar pada isi, desain dan tampilan situs web. Hasil uji usability mengarahkan keputusan dan memungkinkan untuk mengambil lompatan besar menuju user experience (pengalaman pengguna) yang lebih baik(Blakinston, 2015).

\section{Responden}

Pada pengujian usability dengan menggunakan metode Cognitive Walkthrough, Nielsen menjelaskan bahwa jumlah penguji dapat mempengaruhi identifikasi masalah usability pada situs web(Nielsen, 2000). Satu responden diprediksi dapat mengidentifikasi permasalahan pada uji usability kurang lebih sebesar 25 persen, sedangkan 15 responden diprediksi dapat mengidentifikasi permasalahan sebesar 100 persen. Nielsen juga menyatakan bahwa evaluasi usability dilakukan dengan 15 penguji tetapi ia juga menganggap bahwa pengujian dapat dilakukan dengan lima penguji. Pengujian dengan sejumlah lima responden mampu mengidentifikasi sebagian besar permasalahan pada uji usability (kurang lebih 85 persen) tanpa perlu melibatkan banyak sumber daya atau pengguna. Hubungan jumlah permasalahan dengan jumlah responden dapat dilihat pada Gambar 1.

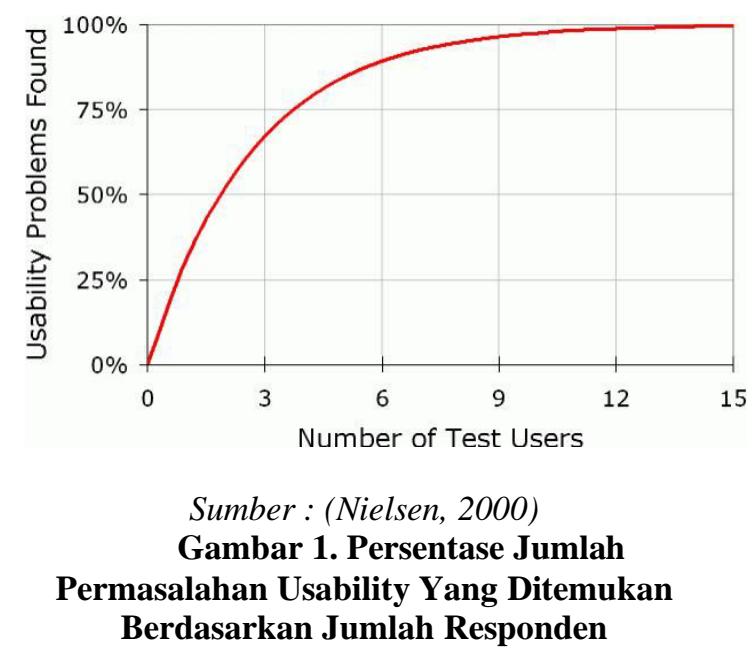


Menurut Nielsen, jumlah peserta pengujian pada studi usability adalah lima peserta (Nielsen, 2012). Hal ini memungkinkan penelitian menemukan hampir sama banyaknya masalah usability menggunakan peserta pengujian yang lebih banyak. Pengujian usability dengan sejumlah lima responden hampir selalu mendekati rasio antara manfaat dan biaya maksimum pengujian. Responden pada uji usability dengan metode cognitive walkthrough merupakan reviewer, pengembang, desainer, personil usability, atau ahli konten. Namun, beberapa Cognitive Walkthrough dapat juga responden meliputi target end user (George, 2008).

Pada pengujian usability dengan menggunakan metode SUS, responden dapat terdiri dari 5 (lima) responden(Pudjoatmojo \& Wijaya, 2016). Namun Alroobaea \& Mayhew menyatakan tidak ada jumlah responden yang pasti untuk mendapatkan hasil evaluasi usability(Alroobaea \& Mayhew, 2014). Akan tetapi, aturan $16 \pm 4$ (artinya jumlah pengguna antara $16-4$ sampai dengan $16+4)$ menghasilkan hasil uji dengan tingkat validitas yang tinggi.

\section{Cognitive Walkthrough}

Menurut Lewis dalam Bligard dan Osvalder, Cognitive Walkthrough adalah metode pengujian usability dengan satu atau lebih aspek yang dinilai melalui beberapa skenario tugas dan sejumlah pertanyaan untuk menggali permasalahan dari perspektif pengguna(Bligard \& Osvalder, 2013). Menurut Hwang, cognitive walkthrough ialah metode yang berbasiskan teori. Aspek-aspek yang mengevaluasi setiap langkah dibutuhkan untuk melakukan tugas yang mengacu pada skenario, dan mencari permasalahan usability yang akan mengganggu eksplorasi(Hwang, 2010).
Menurut Jacobsen dan John, Cognitive Walkthrough terdiri dari dua tahapan yaitu tahap persiapan dan tahap eksekusi(Jacobsen \& John, 2000). Tahapan persiapan terdiri dari studi literatur, mempelajari sistem yang akan diuji, menentukan responden dan menyusun skenario tugas yang harus dikerjakan oleh responden. Tahapan eksekusi terdiri dari rangkaian aksi Walkthrough berurut dan perekaman permasalahan. Tahapan pengujian Cognitive Walkthrough dapat dilihat pada Gambar 2.

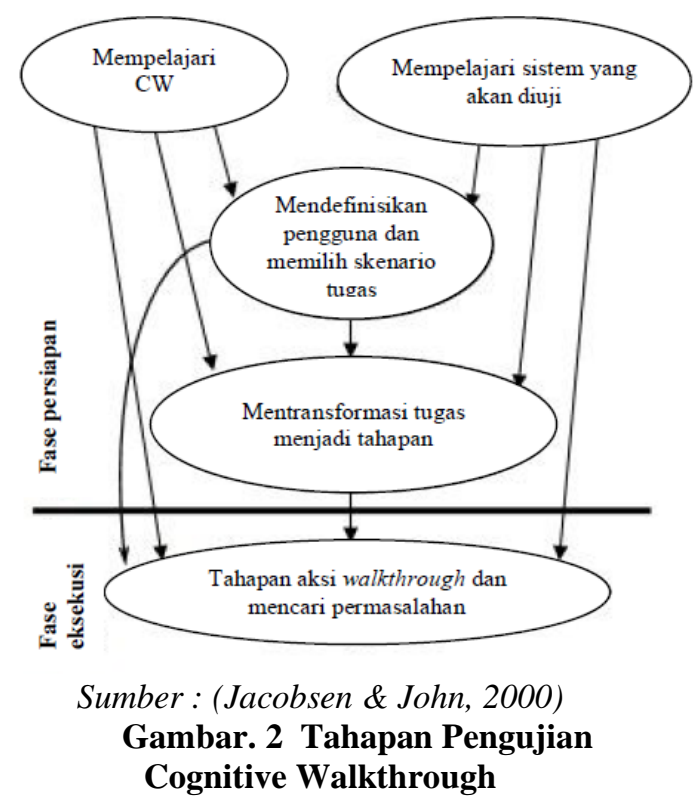

\section{System Usability Scale (SUS)}

System Usability Scale (SUS) adalah metode berbasis kuesioner yang dapat digunakan untuk mengetahui sejauh mana kegunaan suatu sistem dari pandangan subyektif pengguna(Brooke, 2013). SUS memiliki 10 pertanyaan yang harus dijawab oleh responden. Responden pada metode SUS adalah pengguna yang telah menggunakan sistem yang akan diuji. Berikut ini adalah sepuluh pertanyaan dari SUS yang diadopsi dari penelitian Sharfina dan Santoso(Sharfina \& Santoso, 2016): 1. Saya berpikir akan menggunakan sistem ini lagi 
2. Saya merasa sistem ini rumit untuk digunakan

3. Saya merasa sistem ini mudah digunakan

4. Saya membutuhkan bantuan dari orang lain atau teknisi dalam menggunakan sistem ini

5. Saya merasa fitur-fitur sistem ini berjalan dengan semestinya

6. Saya merasa ada banyak hal yang tidak konsisten (tidak serasi pada sistem ini)

7. Saya merasa orang lain akan memahami cara menggunakan sistem ini dengan cepat

8. Saya merasa sistem ini membingungkan

9. Saya merasa tidak ada hambatan dalam menggunakan sistem ini

10. Saya perlu membiasakan diri terlebih dahulu sebelum menggunakan sistem ini.

Metode SUS menggunakan skala likert pada jawaban pertanyaan. Skala likert memiliki 5 pilihan jawaban, yaitu sangat tidak setuju, tidak setuju, raguragu, setuju, dan sangat setuju. Skor masing-masing jawaban mulai dari 0 sampai 5.

Menurut Sauro, untuk menghitung skor SUS terdapat beberapa aturan (Sauro, 2011), yaitu:

1. Untuk item pertanyaan dengan nomor ganjil $(1,3,5,7,9)$, bobot diperoleh dengan mengurangi 1 untuk setiap skor yang diperoleh.

2. Untuk item pertanyaan dengan nomor genap $(2,4,6,8,10)$, bobot yang diperoleh adalah 5 dikurangi skor yang diperoleh untuk setiap item genap .

3. Hasil dari pembobotan kemudian dikalikan dengan 2,5.

Setelah ditemukan hasil untuk setiap responden, skor SUS keseluruhan dapat diperoleh dengan menghitung rata-rata seluruh nilai responden.
Skor SUS memiliki rentang nilai 0100(Aprilia et al., 2015). Untuk mengetahui bagaimana kualitas dari suatu perangkat lunak yang diuji, hasil perhitungan rata-rata seluruh nilai responden dibandingkan dengan nilai pada bagan penilaian SUS pada Gambar 3.

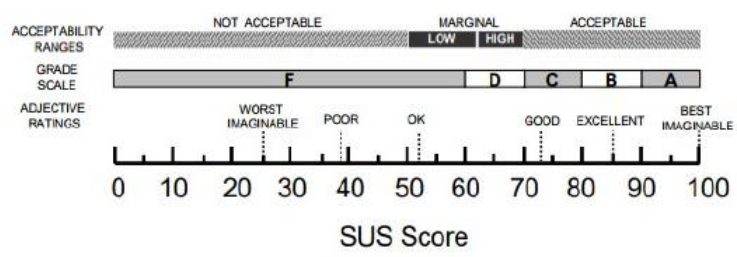

Sumber : (Aprilia et al., 2015)

Gambar. 3 Bagan Penilaian System Usability Scale (SUS)

Secara matematis, rumus perhitungan skor SUS untuk setiap responden dapat diformulasikan seperti pada rumus berikut ini[21]:

$$
\text { Nilai SUS }=\frac{\sum_{i=0}^{n} X i}{N}
$$

dimana Xi adalah jumlah nilai seluruh pertanyaan dikali 2,5 pada responden kei dan $\mathrm{N}$ adalah jumlah responden.

Skor SUS yang dihasilkan kemudian diinterpretasikan dalam beberapa penilaian(Bangor et al., 2008) sebagai berikut:

1. Acceptability Ranges: Interpretasi skor SUS berdasarkan penerimaan pengguna. Skala peringkat yang digunakan adalah Not Acceptable, Marginal, dan Acceptable

2. Grade Scale: Skor SUS dikelompokkan menjadi 5 grade, yaitu A (skor antara 90-100), B (skor antara 80-90), C (skor antara 70-80), D (skor antara 60-70), dan F (skor di bawah 60)

3. Adjectives Rating: Merupakan kata sifat yang menterjemahkan skor numerik SUS ke dalam penilaian absolut terhadap usability. Skala 
peringkat adjectives ini terdiri dari Worst Imaginable, Awful, Poor, OK, Good, Excellent, Best Imaginable.

4. Percentiles: Perhitungan persentil membandingkan data mentah hasil penelitian dengan database penelitian yang telah dilakukan sebelumnya. Skor SUS rata-rata adalah 68. Hal ini menunjukkan bahwa skor SUS di atas 68 berarti di atas rata-rata (above average) sedangkan skor SUS di bawah 68 berarti di bawah rata-rata (below average).

5. Promoters and Detractors: Sauro mengkorelasikan skor SUS dengan Net Promoter Score (NPS)(Sauro, 2011). NPS merupakan survei tingkat kepuasan dan keloyalan pelanggan/ pengguna terhadap sebuah produk yang berkaitan dengan persentase kemungkinan pengguna merekomendasikan produk tersebut pada orang lain(Hanifah et al., 2018).

\section{HASIL DAN PEMBAHASAN}

Sistem yang diuji pada penelitian ini adalah situs web STT Wastukancana. Situs web ini memiliki sembilan menu, yaitu Tentang Kami, Akademik, Jurusan, Penelitian dan Publikasi, Civitas, Kemahasiswaan, Alumni, Layanan, dan Download. Situs web ini digunakan sebagai media informasi mengenai kegiatan akademik di STT Wastukancana. Selain itu, situs web ini juga digunakan sebagai media promosi STT Wastukancana ke masyarakat luas.

Pengujian ini dilakukan pada 30 responden dengan rincian 10 responden diberikan pengujian dengan metode Cognitive Walkthrough dan 20 responden diberikan pengujian SUS. Responden terdiri dari mahasiswa, dosen, dan karyawan STT, serta stakeholder di luar lingkungan STT Wastukancana. Pemilihan responden menggunakan teknik purposive sampling yaitu pemilihan sampel yang dilakukan menggunakan kriteria tertentu. Kriteria tersebut adalah pengguna yang telah mahir dalam mengoperasikan komputer dan mencari informasi menggunakan situs web. Selain itu dipertimbangkan juga terkait pengetahuan, keterampilan dan frekuensi responden dalam menggunakan internet, web browser, website, dan search engine. Hal ini dapat diketahui melalui kuesioner yang disebarkan ke calon responden.

\section{Pengujian Cognitive Walkthrough}

Sebelum tahapan eksekusi, pada pengujian Cognitive Walkthrough perlu dilakukan penyusunan scenario tugas yang kemudian diubah menjadi tahapan pengerjaan yang harus dikerjakan oleh responden. Skenario tugas ditentukan berdasarkan fitur-fitur yang tersedia di situs web STT Wastukancana. Pada Tabel 1 dapat dilihat penjelsan mengenai scenario tugas tersebut.

Perekaman pengujian dilakukan menggunakan perangkat lunak penangkap aktivitas layar komputer. Aplikasi ini digunakan untuk merekam segala interaksi responden terhadap antarmuka situs web STT Wastukancana. Aplikasi yang digunakan adalah Bandicam versi 4.4.1. Hasil dari perekaman pengujian adalah video yang menggambarkan aktivitas responden pada saat menyelesaikan scenario tugas pengujian usability. Pada penelitian ini parameter yang digunakan adalah kesuksesan tugas yang menunjukkan aspek learnability, jumlah waktu yang menunjukkan aspek eficiency dan jumlah kesalahan yang menunjukkan aspek efectiveness.

Tabel 1. Skenario Tugas Pengujian

\begin{tabular}{clc}
\hline ST & \multicolumn{1}{c}{ Tujuan } & $\begin{array}{c}\text { Jumlah } \\
\text { Tahapan }\end{array}$ \\
\hline 1 & $\begin{array}{l}\text { Mengunduh brosur penerimaan siswa } \\
\text { baru }\end{array}$ & 6 \\
\hline 2 & Mencari informasi lowongan kerja & 5 \\
\hline
\end{tabular}




\begin{tabular}{clc}
\hline 3 & $\begin{array}{l}\text { Mencari redaksi jurnal teknologika } \\
\text { edisi ke-5 cetakan ke-2 }\end{array}$ & 5 \\
\hline 4 & $\begin{array}{l}\text { Mencari info tentang Penerimaan } \\
\text { Mahasiswa Baru (PMB) }\end{array}$ & 4 \\
\hline 5 & $\begin{array}{l}\text { Mencari informasi mengenai salah } \\
\text { satu organisasi mahasiswa }\end{array}$ & 4 \\
\hline
\end{tabular}

Tahap eksekusi diawali dengan menempatkan responden pada suatu ruangan yang telah dilengkapi dengan laptop dan jaringan internet. Kemudian responden diberikan penjelasan mengenai tujuan dari pengujian, pemahaman tentang usability, dan skenario yang harus dilakukan oleh responden, serta peraturan pelaksanaan selama pengujian usability berlangsung. Setelah itu dilakukan pengujian usability dengan menggunakan metode walkthrough.

Tingkat penyelesaian scenario diukur dari seberapa jumlah scenario yang dapat diselesaikan oleh seluruh responden. Penilaian yang digunakan adalah sukses (S) dan tidak sukses (F). Data penyelesaian scenario tugas dapat dilihat pada Tabel 2.

Aspek learnability dapat diperoleh dengan melakukan perhitungan success rate. Success rate adalah presentase scenario tugas yang dapat diselesaikan dengan benar oleh responden(Nielsen, 2012). Berdasarkan data penyelesaian scenario tugas, didapatkan hasil presentase success rate sebesar $96 \%$. Hal ini menunjukkan bahwa tingkat learnability pada situs web STT Wastukancana masih di atas rata-rata.

Tabel 2. Data Penyelesaian Skenario Tugas

\begin{tabular}{cccccc}
\hline & ST1 & ST2 & ST3 & ST4 & ST5 \\
\hline R1 & S & S & S & S & S \\
\hline R2 & S & S & S & F & S \\
\hline R3 & S & S & S & S & S \\
\hline R4 & S & S & S & S & S \\
\hline R5 & S & S & S & S & S \\
\hline R6 & S & S & S & F & S \\
\hline R7 & S & S & S & S & S \\
\hline R8 & S & S & S & S & S \\
\hline R9 & S & S & S & S & S \\
\hline R10 & S & S & S & S & S \\
\hline
\end{tabular}

Jumlah kesalahan yang dilakukan menunjukkan aspek effectiveness. Terdapat dua responden yang melakukan kesalahan dimana setiap responden melakukan masing-masing satu kali kesalahan yaitu pada ST ke 4. Tingkat effectiveness dapat diukur dengan menggunakan error rate, yaitu sebesar $4 \%$ sehingga didapatkan quality level sebesar 96\%. Menurut Sauro, nilai ratarata kesalahan per scenario tugas adalah sebensar 0,7 dengan 2 dari 3 pengguna melakukan kesalahan(Sauro, 2012). Berdasarkan error rate yang diperoleh dapat disimpulkan bahwa tingkat effectiveness situs web STT Wastukancana masih di atas rata-rata.

Jumlah waktu penyelesaian skenario merupakan waktu yang diperlukan oleh responden untuk menyelesaikan setiap scenario tugas. Waktu dihitung mulai awal mengerjakan scenario sampai tugas tersebut selesai atau gagal diselesaikan. Data waktu penyelesaian scenario tugas setiap responden dapat dilihat pada Tabel 3.

Tabel 3. Data Waktu Penyelesaian Skenario

\begin{tabular}{cccccc}
\multicolumn{7}{c}{ Tugas } \\
\hline ST1 & ST2 & ST3 & ST4 & ST5 \\
\hline R2 & 73 & 22 & 33 & 9 & 2 \\
\hline R3 & 78 & 51 & 59 & 53 & 6 \\
\hline R4 & 72 & 66 & 54 & 17 & 4 \\
\hline R5 & 52 & 41 & 45 & 12 & 12 \\
\hline R6 & 59 & 33 & 55 & 106 & 11 \\
\hline R7 & 33 & 63 & 40 & 14 & 2 \\
\hline R8 & 55 & 37 & 41 & 20 & 6 \\
\hline R9 & 58 & 24 & 50 & 34 & 2 \\
\hline R10 & 77 & 51 & 19 & 18 & 24 \\
\hline
\end{tabular}

Efisiensi dapat diukur dengan menghitung waktu untuk menyelesaikan tugas, dimana waktu dapat berupa menit atau detik yang dibutuhkan pengguna dalam menyelesaikan tugas (Mifsud, 2015). Tingkat efficiency dapat diperoleh dari perhitungan time based efficiency. Hasil perhitungan time based efficiency pada penelitian ini adalah sebesar 0,07 
skenario tugas per detik. Hal tersebut menunjukkan bahwa rata-rata setiap detik responden dapat menyelesaikan sejumlah $7 \%$ dari setiap scenario tugas yang diberikan atau setiap tugas membutuhkan waktu penyelesaian ratarata selama 14 detik.

\section{Pengujian System Usability Scale (SUS)}

Data yang digunakan untuk mengukur aspek satisfaction adalah data kuesioner System Usability Scale (SUS) yang telah disebarkan kepada 20 responden. Responden pada pengujian SUS ini merupakan pengguna situs web STT Wastukancana. Berdasarkan hasil kuesioner tersebut diperoleh nilai ratarata SUS sebesar 86,25 sehingga masuk ke dalam grade scale $\mathrm{B}$ dengan adjective ranges excellent dan acceptability ranges kategori acceptable.

\section{Rekomendasi}

Berdasarkan hasil pengujian dengan metode Cognitive Walkthrough dan SUS, terdapat beberapa rekomendasi perbaikan untuk situs web STT Wastukancana. Rekomendasi perbaikan ini didasarkan pada permasalahan yang muncul dari pengujian Cognitive Walkthrough dan juga saran dari responden. Rekomendasi yang diberikan dapat berupa perbaikan antarmuka atau juga perbaikan fungsionalitas sistem. Rekomendasi perbaikan tersebut adalah sebagai berikut:

1. Menambahkan menu pencarian untuk mempermudah pengguna menemukan informasi dengan cepat.

2. Meletakkan informasi penting seperti informasi Penerimaan Mahasiswa Baru (PMB) di beranda situs web.

3. Menambahkan konten situs web yang belum lengkap sehingga situs web menjadi lebih informatif.

4. Meningkatkan kualitas foto-foto yang ada pada situs web.

\section{SIMPULAN}

Berdasarkan hasil pengujian yang telah dilakukan dengan menggunakan metode cognitive walkthrough dan system usability scale (SUS) diperoleh tingkat learnability sebesar 96\%, effectiveness sebesar 96\%, efficiency sebesar 0,07 detik, dan aspek satisfaction dengan nilai SUS 86,25 dan acceptability ranges berada di kategori acceptable. Hal tersebut menunjukan bahwa situs web STT Wastukancana sudah sangat baik namun tetap membutuhkan perbaikan agar dapat lebih maksimal dalam penggunaannya. Oleh karena itu, berdasarkan hasil pengujian diberikan rekomendasi perbaikan berupa perbaikan antarmuka dan perbaikan system. Perbaikan antarmuka meliputi peletakan informasi penting di halaman beranda, melengkapi konten yang masih kosong, dan meningkatkan kualitas foto yang ada di dalam situs web. Perbaikan system yaitu menambahkan fitur pencarian yang dapat mempermudah pengguna mencari informasi dengan cepat.

\section{DAFTAR PUSTAKA}

Alroobaea, R., \& Mayhew, P. J. (2014). How many participants are really enough for usability studies? Proceedings of 2014 Science and Information Conference, SAI 2014, 48-56.

Aprilia, I. H. N., Santoso, P. I., \& Ferdiana, R. (2015). Pengujian Usability Website Menggunakan System Usability Scale Website Usability Testing using System Usability Scale. Jurnal IPTEKKOM, 17(1), 31-28.

Arijaya, I. G. N. P., Pradnyana, I. M. A., \& Wirawan, I. M. A. (2019). Usability Testing in Tourism Object Management System. 3rd 
International Conference on Innovative Research Across Disciplines (ICIRAD 2019), 139144.

Audi, M., Rokhmawati, R. I., \& Azzahra, H. M. (2018). Analisis Aspek Usability dan User Experience Website dan Aplikasi Mobile Radio Streaming ( Studi Pada Website dan Aplikasi Mobile Radio Prambors ). Jurnal Pengembangan Teknologi Informasi Dan Ilmu Komputer (JPTIIK) Universitas Brawijaya, 12(2), 6391-6400.

Bangor, A., T.Kortum, P., \& Miller, J. T. (2008). An Empirical Evaluation of the System Usability Scale. International Journal of HumanComputer Interaction, 24(6), 574594.

Blakinston, R. (2015). Usability testing a practical guide for librarians. Rowman \& Littlefield.

Bligard, L.-O., \& Osvalder, A.-L. (2013). Enhanced Cognitive Walkthrough: Development of the Cognitive Walkthrough Method to Better Predict, Identify, and Present Usability Problems. Advances in Human-Computer Interaction.

Brooke, J. (2013). SUS: a retrospective. Journal of Usability Studies, 8(2), 29-40.

George, C. A. (2008). User-Centred Library Websites: Usability evaluation methods.

Hanifah, S., Rahayu, A., \& Dirgantari, P. D. (2018). Gambaran Brand Experience Dan Brand Love Iphone Pada Komunitas Fanspage Facebook Iphone Indonesia. Journal of Business Management Education, 3(1), 1-10.

Hwang, W. (2010). Number of people required for usability evaluation: the $10 \pm 2$ rule. Communications of the ACM, 53(5), 130-133.

Jacobsen, N., \& John, B. (2000). Two case studies in using cognitive walkthrough for interface evaluation. http://reportsarchive.adm.cs.cmu.edu/anon/2000 /CMU-CS-00-132.pdf

Kurnia, R. S., Utami, E., \& Al-Fatta, H. (2017). Pengujian Usability Antarmuka Aplikasi Braille Smart Pada Siswa Tunanetra. Jurnal Informasi Interaktif, 2(1), 21-28.

Kusumah, M. A. A., Rokhmawati, R. I., \& Amalia, F. (2019). Evaluasi Usability Pada Website Ecommerce XYZ Dengan Menggunakan Metode Cognitive Walkthrough dan System Usability Scale (SUS). Jurnal Pengembangan Teknologi Informasi Dan Ilmu Komputer, 3(5), 4340-4348.

Nielsen, J. (2000). Designing Web Usability. New Riders Publishing.

Nielsen, J. (2012, January). Usability 101: Introduction to Usability. Nielsen Norman Group. https://www.nngroup.com/articles/ usability-101-introduction-tousability/

Pradini, R. S., Kriswibowo, R., \& Ramdani, F. (2019). Usability Evaluation on the SIPR Website Uses the System Usability Scale and Net Promoter Score. Proceedings of 2019 4th International Conference on Sustainable Information Engineering and Technology (SIET 2019), 280-284.

Pudjoatmojo, B., \& Wijaya, R. (2016). Tes Kegunaan (Usability Testing) Pada Aplikasi Kepegawaian Dengan Menggunakan System Usability Scale (Studi Kasus: Dinas Pertanian Kabupaten Bandung). Seminar Nasional Teknologi Informasi Dan Multimedia 2016.

Raharjo, P., Kusuma, W. A., \& Sukoco, H. (2016). Uji Usability Dengan 
Metode Cognitive Walkthrough Pada Situs Web Perpustakaan Universitas Mercu Buana Jakarta. Jurnal Pustakawan Indonesia, 15(1-2), 19-27.

Sauro, J. (2011). practical guide to the System Usability Scale: Background, benchmarks, \& best practices. Measuring Usability LLC.

Sauro, J. (2012). Measuring Errors In The User Experience. https://measuringu.com/errors-ux/

Setiawati, A., Rahim, A., \& Kisbianty, D. (2018). Pengembangan dan Pengujian Aspek Usability pada Sistem Informasi Perpustakaan ( Studi Kasus: STIKOM Dinamika Bangsa Jambi ). Jurnal Ilmiah Sistem Informasi, Teknologi Informasi Dan Sistem Komputer (PROCESSOR), 13(1).

Sharfina, Z., \& Santoso, H. B. (2016). An Indonesian adaptation of the System Usability Scale (SUS). 2016 International Conference on Advanced Computer Science and Information Systems (ICACSIS), 145-148. 